\title{
СКІЛЬКИ МАЮТЬ ТА ХОЧУТЬ МАТИ ДІТЕЙ ЖІНКИ ДІТОРОДНОГО ВІКУ В УКРАÏ̈І
}

\author{
ДВНЗ «Тернопільський державний медичний університет імені І.Я. Горбачевського МОЗ України», \\ м. Тернопіль, Україна
}

\begin{abstract}
Мета: вивчити та проаналізувати народжуваність дітей жінками дітородного віку.
Матеріали і методи. Використано дані галузевої статистики щодо народжуваності населення, дані соціологічного опитування жінок Хмельницької області.

Результати. Вивчення причин зниження народжуваності дітей в сучасних умовах показує, що цьому сприяють багато таких чинників, як зниження життєвого рівня населення, зумовлене соціально-економічною кризою, трудова еміграція жінок, державні виплати грошової допомоги при народженні дитини та субсидії, які далеко не компенсують витрати на дитину.

Висновки. Отримані результати підтвердили те, що при сприятливих соціально-економічних умовах жінки дітородного віку мали б 2,02 дитини пересічно на одну жінку, що відповідало б стаціонарному типу відтворення населення.
\end{abstract}

КЛЮЧОВІ СЛОВА: народжуваність; відтворення; вікові групи.

31991 р. в Україні спостерігається зменшення чисельності населення, яке на сьогодні складає більше 7 млн осіб. Зменшення населення з роками підсилюється, що є результатом дії багатьох соціальних, соціально-демографічних, медичних та інших чинників [1-3, 5, 6]. Нас особливо цікавить питання, що буде 3 народжуваністю в Україні в перспективі. А це залежить передусім від процесу народження дітей жінками дітородного віку. Більш як половина українських сімей не має дітей! При цьому найчастіше українці наважуються на одну дитину, а кількість охочих утримувати двох і більше неухильно скорочується [4, 7]. Зокрема, в 2017 р. у країні зареєстровано 63,5 \% бездітних сімей. Для порівняння: у 2007 р. - 59,2 \%, у 1999 р. - 55,8 \%. 3 сімей із дітьми одну дитину мали 70,7 \% батьків, порівняно $з$ 68,1 \% у 2007, і $60 \%$ - у 1999 р. До того ж, кожна четверта сім'я утримувала двох дітей 25,5\% (в 2007 р. - 27,9 \%, у 1999 р. - 34,3\%, а троє і більше - 3,8 \% (в 2007 р. - 4 \%, у 1999 р. 5,7 \%). Фахівці з демографії б'ють тривогу: такими темпами українців скоро буде зовсім мало! А через кілька сотень років невідомо, чи залишаться вони взагалі. Найбільше сімей із дітьми до 18 років припадає на Закарпатську, Чернівецьку, Волинську, Рівненську, Івано-Франківську, Тернопільську та Львівську області $[3,5,7]$.

Мета роботи: вивчити та проаналізувати народжуваність дітей жінками дітородного віку.

Матеріали і методи. Використано дані галузевої статистики щодо народжуваності населення,

(С) О.В. Левченко, В.Л. Смірнова, А.О. Голяченко, 2018 дані соціологічного опитування жінок Хмельницької області.

Результати дослідження та їх обговорення. Ми провели анкетування 282 жінок дітородного віку, в яких з'ясували, скільки вони хочуть мати дітей. Дослідження проводили протягом 20162017 рр. 3'ясовано, що у найбільш дітородних вікових групах 20-24 роки та 25-29 років, жінки мають, відповідно, 0,24 та 0,47 дітей в середньому на одну жінку, а хотіли б мати дітей, відповідно, 2,01 та 2,02. Тобто мав би бути стаціонарний тип відтворення населення.

Результати дослідження наведено в таблиці 1.

Загалом опитано 282 жінки, 3 них у віці 2024 роки - 76 (27,0 \%), 25-29 років - 88 (31,2 \%), 30 і старше - 118 (41,8 \%).

Як видно 3 таблиці 1, загалом мали одну дитину $(34,5 \pm 2,8) \%$, двоє дітей - $(12,4 \pm 1,9) \%$, троє дітей - $(1,4 \pm 0,7) \%$, четверо і більше - $(0,3 \pm 0,3) \%$.

Не мали дітей $(51,4 \pm 2,4) \%$, тобто більше половини жінок так і не виконали свою дітородну фрункцію.

Всього жінками було народжено 185 дітей, що складало 0,66 дітей на одну жінку.

Тепер стосовно їх бажання мати дітей: одну дитину хотіли б мати $(6,2 \pm 1,4) \%$, двох дітей $(61,0 \pm 2,9) \%$, трьох дітей - $(14,5 \pm 2,1) \%$, чотирьох і більше - $(1,1 \pm 0,6) \%$. Не відповіли на це питання $(14,8 \pm 2,8) \%$.

Таким чином, число бажаних дітей склало 517, що пересічно становить 1,78 дитини на одну жінку.

Значно кращою $€$ демографрічна картина у жінок основного дітородного віку 20-24 та 
Таблиця 1. Скільки мають і хочуть мати дітей жінки дітородного віку

\begin{tabular}{|c|c|c|c|c|c|c|c|c|}
\hline Вік жінок & \multicolumn{2}{|c|}{$20-24$} & \multicolumn{2}{|c|}{$25-29$} & \multicolumn{2}{|c|}{30 і старше } & \multicolumn{2}{|c|}{ Всього } \\
\hline Число обстежених & & 6 & & 38 & & 8 & & 82 \\
\hline Показники & $\begin{array}{l}\text { Число } \\
\text { жінок }\end{array}$ & Діти & $\begin{array}{l}\text { Число } \\
\text { жінок }\end{array}$ & Діти & $\begin{array}{l}\text { Число } \\
\text { жінок }\end{array}$ & Діти & $\begin{array}{l}\text { Число } \\
\text { жінок }\end{array}$ & Діти \\
\hline $\begin{array}{r}\text { Мали: } \\
1 \text { дитину } \\
2 \text { дитини } \\
3 \text { дитини } \\
4 \text { дитини } \\
\end{array}$ & $\begin{array}{l}6 \\
4 \\
- \\
1\end{array}$ & $\begin{array}{c}7,9 \pm 2,9 \\
5,3 \pm 2,6 \\
- \\
1,3 \pm 1,3\end{array}$ & $\begin{array}{c}36 \\
4 \\
1 \\
- \\
\end{array}$ & $\begin{array}{c}40,9 \pm 5,2 \\
4,5 \pm 2,2 \\
1,1 \pm 1,1 \\
-\end{array}$ & $\begin{array}{c}58 \\
28 \\
3 \\
- \\
\end{array}$ & $\begin{array}{c}49,2 \pm 4,6 \\
23,7 \pm 3,9 \\
2,5 \pm 1,4 \\
- \\
\end{array}$ & $\begin{array}{c}100 \\
36 \\
4 \\
1 \\
\end{array}$ & $\begin{array}{c}34,5 \pm 2,8 \\
12,4 \pm 1,9 \\
1,4 \pm 0,7 \\
0,3 \pm 0,3\end{array}$ \\
\hline Не мали дітей & 65 & $85,5 \pm 4,0$ & 47 & $53,4 \pm 5,3$ & 29 & $24,6 \pm 4,0$ & 141 & $51,4 \pm 2,9$ \\
\hline Число народжених дітей & & 18 & & 41 & & 126 & & 185 \\
\hline $\begin{array}{l}\text { Число народжених дітей } \\
\text { пересічно на одну жінку }\end{array}$ & & 0,24 & & 0,47 & & 1,07 & & 0,66 \\
\hline $\begin{array}{c}\text { Хотіли б мати: } \\
1 \text { дитину } \\
2 \text { дитини } \\
3 \text { дитини } \\
4 \text { дитини } \\
5 \text { дітей } \\
\end{array}$ & $\begin{array}{c}9 \\
48 \\
13 \\
1 \\
1 \\
\end{array}$ & $\begin{array}{c}11,8 \pm 3,9 \\
63,2 \pm 5,5 \\
17,1 \pm 4,3 \\
1,3 \pm 1,3 \\
1,3 \pm 1,3 \\
\end{array}$ & $\begin{array}{c}3 \\
62 \\
14 \\
1 \\
1 \\
\end{array}$ & $\begin{array}{c}3,4 \pm 1,9 \\
70,5 \pm 4,9 \\
15,9 \pm 3,9 \\
1,1 \pm 1,1 \\
1,1 \pm 1,1\end{array}$ & $\begin{array}{c}6 \\
63 \\
15 \\
1 \\
1\end{array}$ & $\begin{array}{c}5,1 \pm 2,0 \\
53,4 \pm 4,6 \\
12,7 \pm 3,1 \\
0,8 \pm 0,8 \\
0,8 \pm 0,8\end{array}$ & $\begin{array}{c}18 \\
173 \\
42 \\
3 \\
3\end{array}$ & $\begin{array}{c}6,2 \pm 1,4 \\
61,0 \pm 2,9 \\
14,5 \pm 2,1 \\
1,0 \pm 0,6 \\
1,0 \pm 0,6\end{array}$ \\
\hline Не відповіли на питання & 4 & $5,2 \pm 2,5$ & 7 & $8,0 \pm 2,9$ & 32 & $12,1 \pm 4,1$ & 43 & $14,8 \pm 2,1$ \\
\hline Число бажаних дітей & & 153 & & 178 & & 186 & & 517 \\
\hline $\begin{array}{l}\text { Число бажаних дітей } \\
\text { пересічно на одну жінку }\end{array}$ & & 2,01 & & 2,02 & & 1,58 & & 1,78 \\
\hline
\end{tabular}

25-29 років. У жінок у віці 20-24 роки мали одну дитину $(7,9 \pm 2,9) \%$, двоє дітей - $(5,3 \pm 7,6) \%$, троє дітей - $(1,3 \pm 1,3) \%$, четверо і більше - не мали. Не мали дітей 65 жінок, тобто $(85,5 \pm 4,0) \%$. Число народжених дітей склало 18, що пересічно становить 0,24 на одну жінку.

Хотіли б мати дітей у віці 20-24 роки: одну дитину - $(11,8 \pm 3,9) \%$, двох дітей - $(63,2 \pm 5,5) \%$, трьох дітей - $(17,1 \pm 4,3) \%$, чотирьох - $(1,3 \pm 1,3) \%$, п'ять $(1,3 \pm 1,3) \%$. Не відповіли на це питання $(5,2 \pm 2,5) \%$.

Таким чином, число бажаних дітей в цій віковій групі склало 153, що пересічно становить 2,01 дитини на одну жінку.

Аналогічні показники ми маємо в жінок у віковій групі 25-29 років, одну дитину мали $(40,9 \pm 5,2) \%$, двоє дітей - $(4,5 \pm 2,2) \%$, троє - $(1,1 \pm 1,1) \%$, четверо і більше - не мали. Не мали дітей 47 жінок, тобто $(53,4 \pm 5,3) \%$. Число народжених дітей склало 41, що пересічно становить 0,47 на одну жінку.

Варто відзначити, що частка жінок у віковій групі 25-29 років, які б бажали мати лише одну дитину знизилась, порівняно 3 попередньою віковою групою до $(3,4 \pm 1,8) \%$, а число бажаних двох дітей збільшилась до $(70,5 \pm 4,9) \%$. Загалом жінки цієї вікової групи хотіли б мати 188 дітей, що пересічно складає 2,02 дитини на одну жінку, що майже відповідає показнику в групі жінок 20-24 роки.

Основними причинами, які стримували народження дітей в опитаних жінок подані у порядку зростання: нестача дошкільних закладів $(1,7 \pm 0,7) \%$, прагнення жінки до професійного зростання $(4,9 \pm 1,2) \%$, складність виховання дітей $(5,4 \pm 1,2) \%$, страх перед пологами $(5,7 \pm 1,2) \%$, погані житлові умови $(7,4 \pm 1,4) \%$, незадовільний стан здоров'я жінки $(12,9 \pm 1,8) \%$, великі грошові витрати на дитину $(22,9 \pm 2,2) \%$, інші причини $(9,7 \pm 1,6) \%$, не відповіли $(29,4 \pm 2,4) \%$.

Таким чином, ці дві основні дітородні групи жінок мають майже однакові показники бажаного дітонародження, це б сприяло забезпеченню хоча б стаціонарного відтворення населення. Але для цього потрібно подолати багато причин.

\section{Висновки}

Отримані результати підтвердили те, що при сприятливих соціально-економічних умовах жінки дітородного віку мали б 2,02 дитини пересічно на одну жінку, що відповідало б стаціонарному типу відтворення населення.

Перспективи подальших досліджень полягають у вивченні причин зниження рівня народжуваності в Україні.

\section{Список літератури}

1. Голяченко О. М. Актуальні проблеми здоров'я української людності / О. М. Голяченко, А. О. Голяченко, А. Г. Шульгай. - Тернопіль : Лілея, 2012. - 116 с.

2. Демографрічні перспективи України до 2026 року. - К., 1999. - 55 с.

3. Демограффічні перспективи України: 2000-2075 роки / Е. М. Лібанова, О. В. Макарова, О. В. Позняк [та ін.] // Зайнятість та ринок праці : міжвід. наук. зб. - К. : РВПС України НАН України, 1999. - Вип. 11. - С. $126-141$.

4. Курило И. Рождаемость и родительство в социально-демографическом измерении / И. Курило. - К., 2018. - 124 с. 
5. Лібанова Е. Прогноз демографічного розвитку України на період до 2050 року / Е. Лібанова // Світогляд. - 2008. № 3. - C. 48-51.

6. Про демографрічний прогноз розвитку України до 2050 року : Постанова від 21.11.2007 р. № 313 Національної академії наук України (НАН).

7. Щорічна доповідь про стан здоров'я населення, санітарно-епідеміологічну ситуацію та результати діяльності системи охорони здоров'я України. - К., 2018. - 450 с.

\section{References}

1. Holiachenko, A.A., \& Shulhai, A.H. (2012). Aktualni problemy zdorovia ukrainskoi liudnosti [Actual problems of the health of the Ukrainian people]. Ternopil: Lileia [in Ukrainian].

2. Demohrafichni perspektyvy Ukrainy do 2026 roku [Demographic perspectives of Ukraine till 2026]. (1999). Kyiv [in Ukrainian].

3. Libanova, E.M., Makarova, O.V., \& Pozniak, O.V. (1999). Demohrafichni perspektyvy Ukrainy: $2000-2075$ roky [Demographic perspectives of Ukraine: 2000-2075 years]. Zainiatist ta rynok pratsi - Employment and Labor Market. Kyiv: RVPS of Ukraine of the National Academy of Sciences of Ukraine [in Ukrainian].

4. Kurilo, I. (2018). Rozhdayemost i roditelstvo $v$ sotsialno-demograficheskom izmerenii [Fertility and parenthood in the socio-demographic dimension]. Kiev [in Russian].

5. Libanova, E. (2008). Prohnoz demohrafichnoho rozvytku Ukrainy na period do 2050 roku [The forecast of demographic development of Ukraine for the period up to 2050]. Svitohliad - Worldview, 3, 48-51 [in Ukrainian].

6. Pro demohrafichnyi prohnoz rozvytku Ukrainy do 2050 roku [On the demographic forecast of Ukraine's development by 2050]. Postanova № 313 vid 21. 11. 2007 Natsionalnoi akademii nauk Ukrainy (NAN) - Regulation No. 313 of 21. 11. 2007 of the National Academy of Sciences of Ukraine (NAS) [in Ukrainian].

7. Shchorichna dopovid pro stan zdorovia naselennia, sanitarno-epidemiolohichnu sytuatsiiu ta rezultaty diialnosti systemy okhorony zdorovia Ukrainy [Annual report on the health status of the population, sanitary and epidemiological situation and the results of the health care system of Ukraine]. (2018). Kyiv [in Ukrainian].

\section{СКОЛЬКО ИМЕЮТ И ХОТЯТ ИМЕТЬ ДЕТЕЙ ЖЕНЩИНЫ ДЕТОРОДНОГО ВОЗРАСТА В УКРАИНЕ}

О.В. Левченко, В.Л. Смирнова, А.А. Голяченко

ГВУЗ «Тернопольский государственный медицинский университет имени И.Я. Горбачевского МЗ Украины»,

г. Тернополь, Украина

Цель: изучить и проанализировать рождаемость детей женщинами детородного возраста.

Материалы и методы. Использованы данные отраслевой статистики по рождаемости населения, данные социологического опроса женщин Хмельницкой области.

Результаты. Изучение причин снижения рождаемости детей в современных условиях показывает, что этому способствуют многие такие фракторы, как снижение жизненного уровня населения, обусловленное социально-экономическим кризисом, трудовая эмиграция женщин, государственные выплаты денежной помощи при рождении ребенка и субсидии, которые далеко не компенсируют расходы на ребенка.

Выводы. Полученные результаты подтвердили, что при благоприятных социально-экономических условиях женщины детородного возраста имели бы 2,02 ребенка в среднем на одну женщину, что соответствовало бы стационарному типу воспроизводства населения.

КЛЮЧЕВЫЕ СЛОВА: рождаемость; воспроизведение; возрастные группы.

\section{HOW MANY CHILDREN DO WOMEN OF REPRODUCTIVE AGE HAVE AND WANT TO HAVE IN UKRAINE}

O.V. Levchenko, V.L. Smirnova, A.O. Holyachenko

I. Horbachevsky Ternopil State Medical University

Purpose: to study and analyze number of children born by women of childbearing age.

Materials and Methods. Statistical data on birth rate of population, data from sociological surveys of women in the Khmelnytskyi region were used.

Results. Study of causes of decline in birth rate of children in modern conditions shows that many factors contribute to this: decrease in living standard of the population due to socioeconomic crisis, labor emigration of women, state child support payments and subsidies that come short of covering child-rearing expenses. Due to low living standards, unemployment and other social and economic problems caused by crisis in all spheres of life, Ukrainian families do not have the opportunity now to ensure the appropriate level of spending on children, which is becoming one of the main reasons why birth rate has plummeted. Furthermore, a modern woman wishes more and more to have time to self-actualize in career growth and not only in her role as a mother, and wants to be just a housewife less and less. The spread of choosing not to have children or give birth to only one child among a large number of women is facilitated by the fact that women have to earn money and raise children, and the state does not support much. 
Conclusion. The results we have obtained confirm that, under favorable socioeconomic conditions, women of childbearing age would have 2.02 children on average per woman, which would correspond to a stationary type of reproduction of the population.

KEYWORDS: fertility; reproduction; age groups.

Рукопис надійшов до редакції 11.06.2018 p.

\section{Відомості про авторів:}

Левченко Ольга Володимирівна - лікар-інтерн ДВНЗ «Тернопільський державний медичний університет імені І. Я. Горбачевського МОЗ України»; тел.: +38(0352) 52-72-33.

Смірнова Валентина Леонідівна - доцент кафедри соціальної медицини, організації та економіки охорони здоров'я з медичною статистикою дВНЗ «Тернопільський державний медичний університет імені І. Я. Горбачевського МОЗ України»; тел.: +38(0352) 52-72-33.

Голяченко Андрій Олександрович - доктор медичних наук, профресор кафредри медичної реабілітації ДВНЗ «Тернопільський державний медичний університет імені І. Я. Горбачевського МОЗ України»; тел.: +38(0352) 25-45-77. 